Grunze, H. (1960). Acta cytol. (Philad.), 4, 175.

von Haam, E. (1962). Ibid., 6, 508.

Horn, D., and Siegel, A. (1961). CA (N.Y.), 11, 97.

Johnson, W. D., Koss, L. G., Papanicolaou, G. N., and Seybolt, J. F. (1955). Ibid., 8, 851 .

Koss, L. G., and Durfee, G. R. (1961). Diagnostic Cytology and its Histopathologic Bases. Lippincott, Philadelphia.

Melamed, M. R., and Goodner, J. T. (1964). Acta cytol. (Philad.), $8,104$.

Stewart, F W., Foote, F. W., Jordan, M. J., Bader, G. M., and Day, E. (1963). Cancer (Philad.), 16, i160.

MacDonald, W. C., Brandborg, L. L., Taniguchi, L., and Rubin, C. E. (1963). Ann. intern. Med., 59, 332.

Beh, J. E., and Rubin, C. E. (1964). Cancer (Philad.),

Macfarlane, E. W. E. (1963). Acta cytol. (Philad.), 7, 196.

McLaren, H. C. (1963). The Prevention of Cervical Cancer. English Univ. Press, London.

Marsan, C., and Bertini, B. (1960). Path. et Biol., 8, 343.

Mavrommatis, F. (1962). Schweiz. med. W schr., 92, 1094.

Melamed, M. R., Koss, L. G., and Cliffton, E. E. (1963). Cancer (Philad.), 16, 1537.

Messelt, O. T. (1960). Acta Un. int. Cancr., 16, 1364.

Naylor, B. (1964). Acta cytol. (Philad.), 8, 141.

and Schmidt, R. W. (1964). Lancet, 1,71 i.
Oakland, D. J. (1961). Brit. 7. Surg., 48, 353.

Papanicolaou, G. N., Holmquist, D. G., Bader, G. M., and Falk, E. A. (1958). Cancer (Philad.), 11, 377.

Pe and Koprowska, I. (1951). Ibid., 4, 141.

Petersen, O. (1955). Acta radiol. (Stockh.), Suppl. No. 127

Raskin, H. F., and Pleticka, S. (1964). Acta cytol. (Philad.), 8, 131.

Riaboff, P. J.' (1954). 7. Urol., 72, 62.

Richards, W. C. D., and Spriggs, A. I. (1961). 7. clin. Path., 14, 132.

Richardson, H. L., Queen, F. B., and Bishop, F. H. (1949). Amer. 3. clin. Path., 19, 328.

Rome, D. S., and Olson, K. B. (1961). Acta cytol. (Philad.), 5, 173.

Russell, W. O., Neidhardt, H. W., Mountain, C. F., Griffith, K. M., and Chang, J. P. (1963). Ibid., 7, 1 .

Sandler, H. C. (1964). Ibid., 8, 114 .

Sayk, J. (1960). Cytologie der Cerebrospinalflüssigkeit. Fischer, Jena.

Schade, R. O. K. (1960). Gastric Cytology, Arnold London

Selbach, G. J., and von Haam, E. (1963). Acta cytol. (Philad.), 7, 337.

Spriggs, A. I. (1957a). Proc. 3rd Int. Congr. Clin. Path. (Brussels), p. 309. (1957b). The Cytology of Effusions. Heinemann, London.

and Boddington, M. M. (1959). Brit. f. Haemat., 5, 83.

Stofberg, A. M. M. (1963). Acta haemat. (Basel), 29, 65.

Umiker, W. (1964). Acta cytol. (Philad.), 8, 186.

Woolner, L. B. Anderson, H. A., and Benatz, P. E. (1960). Dis. Chest, $37,278$.

\title{
6-Phosphogluconate Dehydrogenase Activity in Vaginal Fluid: Limitations as a Screening Test for Genital Cancer
}

\author{
C. B. CAMERON, ${ }^{*}$ M.D. ; O. A. N. HUSAIN, $\dagger$ M.D., M.C.PATH.
}

Brit. med. F., 1965, 1, 1529-1530

Recognition that the commoner forms of cancer of the genital tract in women can be cured if treated at an early stage has focused interest in screening tests which can be applied on a wide scale. The current practice of examining cells in smears obtained from the vagina and uterus for evidence of cancerous change is of proved value (MacGregor' and Baird, 1963) but some simpler alternative would be welcome. Bonham and Gibbs (1962) and Bonham (1963) have reported encouraging results, using 6-phosphogluconate dehydrogenase (6-PGD) activity in vaginal fluid as a screening test for uterine cancer. We have independently carried out this biochemical assay in parallel with standard cytological and histological techniques and this report summarizes our findings in certain well-defined clinical groups.

\section{Material and Methods}

Most of 2,480 patients examined were attending gynaecological out-patient departments in London hospitals. Antenatal and post-natal patients were included. Some women were in-patients at the Royal Marsden Hospital with suspected uterine cancer.

Samples of vaginal fluid were collected and 6-PGD activity was determined, using the method of Bonham and Gibbs (1962) modified for a Technicon AutoAnalyzer (Weg and Cameron, to be published). Following Bonham (1963), we accepted 80 units of 6-PGD per g. of dry weight ${ }^{1}$ of sample

\footnotetext{
- Department of Clinical Research, Institute of Cancer Research : Royal Cancer Hospital, and Royal Marsden Hospital, London.

† St. Stephen's Hospital, London.

1 The dry weight is not a convenient parameter as it entails freeze-drying each sample and weighing containers with and without sample. It is also inaccurate when samples are small-that is, less than $3 \mathrm{mg}$ dry weight. We have estimated soluble-protein concentrations in more than 1,000 samples and found that 6-PGD activity per mg. soluble protein in general parallels the enzyme activity per mg. dry weight of sample. For direct comparison with other reported work however, the dry weight parameter has been used in this paper.
}

as the upper limit of normal. Values above this figure were called positive results.

Smears were taken for cytology from the same patients at the same time and reported on by one of four pathologists, using prearranged standardized criteria. Where malignancy was suspected on cytological grounds the final diagnosis was based on histological examination of biopsy material.

\section{Results}

Women with Genital Tract Cancer.-Sixty-six women were found on histological grounds to have some malignant lesion of the genital tract, and Table I summarizes our results in these patients. A positive result was obtained in 53 out of 55 patients with invasive uterine cancer. The result was

TABLE I.-Results of 6-PGD Assay in Patients With Uterine Carcinoma

\begin{tabular}{|c|c|c|c|c|}
\hline - & & Positive & Negative & Total \\
\hline $\begin{array}{l}\text { Carcinoma-in-situ } \\
\text { Epidermoid carcinoma } \\
\text { Adenocarcinoma cervix }\end{array}$ & $\begin{array}{ll}. & \cdots \\
\cdots & \cdots\end{array}$ & $\begin{array}{r}6 \\
36 \\
4\end{array}$ & $\begin{array}{l}5 \\
0 \\
0\end{array}$ & $\begin{array}{r}11 \\
36 \\
4\end{array}$ \\
\hline $\begin{array}{c}\text { Other pelvic carcinoma } \\
\text { invading genital tract }\end{array}$ & $\begin{array}{l}\text { secondarily } \\
\ldots \quad \ldots\end{array}$ & $\begin{array}{l}9 \\
4\end{array}$ & $\begin{array}{l}2 \\
0\end{array}$ & $\begin{array}{r}11 \\
4\end{array}$ \\
\hline
\end{tabular}

negative in two patients (both with adenocarcinoma corpus) who had undergone thorough curettage two weeks previously and in whom cytology showed no malignant cells.

Women Without Genital Tract Cancer.-A high incidence of positive enzyme results was found in women with no clinical or cytological evidence of malignant disease of the genital tract. The percentages of false-positive results found in different age groups are shown in Table II. Before the menopause about one woman in three shows increased enzyme activity, and this ratio increases markédly after the menopause. The phase of the menstrual cycle in which the 
sample of vaginal fluid is taken does not appear to influence the incidence of false-positive reactions in pre-menopausal women (Table III).

TABLE II.-Non-malignant Group. Age Distribution and False-positive

\begin{tabular}{c|c|c}
\multicolumn{3}{c}{ Results of 6-PGD Assay } \\
\hline $\begin{array}{c}\text { Age } \\
\text { (5-year Period) }\end{array}$ & $\begin{array}{c}\text { No. of } \\
\text { Patients }\end{array}$ & $\begin{array}{c}\text { \% with Positive } \\
\text { 6-PGD Assay }\end{array}$ \\
\hline $15-$ & 77 & 32 \\
$20-$ & 328 & 31 \\
25 & 390 & 29 \\
$30-$ & 362 & 35 \\
$35-$ & 302 & 33 \\
$40-$ & 287 & 38 \\
$45-$ & 214 & 41 \\
$50-$ & 188 & 64 \\
$55-$ & 80 & 77 \\
$60-$ & 35 & 80 \\
65 & 25 & 90 \\
$70-$ & 10 & 83 \\
$75-$ & 6 & 82 \\
$80-$ & 11 &
\end{tabular}

TABLE III.-Non-malignant Group. Incidence of False-positive Assays at Different Phases of the Menstrual Cycle

\begin{tabular}{c|c|c}
\hline $\begin{array}{c}\text { Days of Cycle } \\
\text { (M=Day of Onset } \\
\text { of Menstruation) }\end{array}$ & No. of Patients & $\begin{array}{c}\% \text { with } \\
\text { Positive } \\
\text { 6-PGD Assay }\end{array}$ \\
\hline *M-12 & 158 & 31 \\
$13-15$ & 113 & 29 \\
$16-M$ & 244 & 30 \\
\hline
\end{tabular}

- Samples were seldom taken during menstruation, since the presence of blood in a sample greatly increases the probability of a positive result.

The findings during and after pregnancy are summarized in Table IV. The relatively low incidence of false-positive results in the antenatal group is noteworthy.

TABLE IV.-Non-malignant Group. Incidence of False-positive Results in Pregnancy

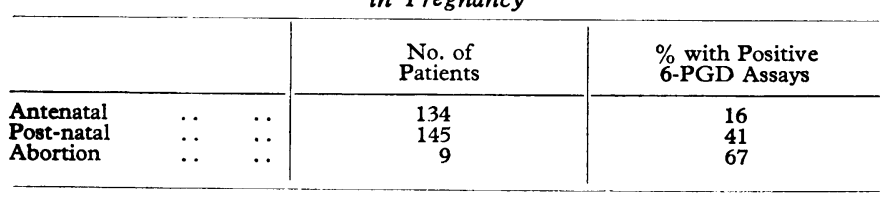

\section{Discussion}

It can be seen that the enzyme test proved reliable in selecting patients with invasive uterine cancer of both body and cervix.

On the other hand, the enzyme test proved disappointing in detecting carcinoma-in-situ in the small number of cases reported. The diagnosis would have been missed in half the patients had 6-PGD activity been the only criterion used. In the present state of our understanding of carcinoma-in-situ it would not be considered tolerable to leave this group untreated. It is, however, possible that the low enzyme activity reflects a very early stage in the natural history of the lesion. There is evidence in the histochemical work of Chayen and Bitensky (personal communication) that increased 6-PGD activity precedes the development of invasive characteristics in tumours of both skin and cervix. If this evidence can be strengthened it may prove possible to divide carcinomain-situ into two stages-one of "quiescence" and one of "incipient invasiveness." Failure to detect "quiescent" cases would then perhaps not be an absolute contraindication to the use of 6-PGD as a screening test.

We were unable to assess the enzyme test in antenatal or post-natal patients as no cases of cancer were encountered in this group.

It is clear that there are conditions much more common than genital cancer which are also associated with increased 6-PGD aetivity. Our data on these non-malignant conditions will be published in another paper. Here we note only that this greatly reduces the specificity of the enzyme assay as a screening test for genital cancer-a positive result has little diagnostic significance. If we proposed to use a second screening test-for example, cytological examination of exfoliated cells-on all women exhibiting raised enzyme levels, a proportion of false-positive results in the enzyme test would be permissible; the extent to which such fallibility was acceptable would, however, depend on the cost and convenience of the enzyme procedure as compared with cytology. We estimate that where the incidence of false-positive results was higher than one in three no useful purpose would be served by applying the enzyme test first, and nothing would be gained by using 6-PGD assay in screening women over the age of 45 , as the incidence of false-positive results in this group average $70 \%$. In younger women the incidence of false-positive reactions, though still high, is not high enough to render the test valueless as a preliminary screening procedure, and in the antenatal group the situation may be even more favourable.

\section{Summary}

We have been able to confirm the findings of Bonham and Gibbs (1962) that $\dot{6}$-phosphogluconate dehydrogenase activity is consistently raised above normal levels in the vaginal fluid of patients with invasive carcinoma of the genital tract. There are, however, serious limitations to the use of the enzyme measurement as a screening test, as half the patients with carcinoma-in-situ do not exhibit increased activity of this enzyme, and there is a high incidence of raised enzyme levels in women without genital cancer.

We are greatly indebted to Dr. I. M. P. Dawson (Westminster Hospital), Dr. H. P. Ferreira (Chelsea Hospital for Women), and Dr. H. E. M. Kay (Royal Marsden Hospital) for their co-operation and for permitting us to use their records. Mr. W. Weg has given us skilful biochemical assistance, and Miss $\mathbf{R}$. Bell has advised on collation of data. The collection of samples was undertaken by clinicians, nurses, and technicians, and we are most grateful for their help.

This work was supported by grants from the Medical Research Council, the Ministry of Health, and the British Empire Cancer Campaign.

\section{REFERENCES}

Bonham, D. G. (1963). Trans. med. Soc. Lond., 80, 30. MacGregor, J. Elizabeth, and Baird, D. (1963).' Ibid., 1, 1631. 